\title{
EFFICACY OF EUPHORBIA HETEROPHYLLA LATEX AGAINST PATHOGENIC BACTERIA AND FUNGI
}

\author{
PRUTHVI ML ${ }^{1 *}$, MAHESH MK ${ }^{1}$, ROHINI SAHAYA MARY ${ }^{2}$ \\ ${ }^{1}$ Department of Botany, Yuvaraja's College, Mysuru, Karnataka, India. ${ }^{2}$ Department of Botany, Teresian College, Mysuru, Karnataka, India. \\ Email: srrohi@gmail.com
}

Received: 04 March 2020, Revised and Accepted: 15 April 2020

\section{ABSTRACT}

Objective: The objective of the study was to determine the antimicrobial activities of Euphorbia heterophylla latex.

Methods: The antibacterial and antifungal activities of acetone, chloroform, and diethyl ether extracts were assayed by disk diffusion method.

Results: The study of plant E. heterophylla latex revealed the presence of medically active metabolites. Bacterial strains such as Staphylococcus aureus, Bacillus subtilis, Proteus vulgaris, and Pseudomonas aeruginosa exhibited a strong zone of inhibition. Acetone extract exerts a potent zone of inhibition against $P$. aeruginosa compared to tetracycline. Fungi, Aspergillus niger, Fusarium oxysporum, and Penicillium sp., were used for the antifungal activity. It was observed that the highest zone of inhibition was noticed against $A$. niger in all the extracts. Interestingly, F. oxysporum and Penicillium sp. showed no zone of inhibition and were resistant to standard drug, fluconazole which was used as a control.

Conclusion: E. heterophylla latex extract was found to be more potent than the standard drugs which were used against both the bacterial and fungal strains.

Keywords: Euphorbia heterophylla, Latex, Antibacterial activity, Antifungal activity.

(C) 2020 The Authors. Published by Innovare Academic Sciences Pvt Ltd. This is an open access article under the CC BY license (http://creativecommons. org/licenses/by/4. 0/) DOI: http://dx.doi.org/10.22159/ajpcr.2020.v13i6.37341

\section{INTRODUCTION}

Medicinal plants play a significant role in providing primary, healthcare services to rural people and are used by about $80 \%$ of the marginal communities in the world [1-3]. Each medicinal plant has its own nutrient constituents along with the phytochemical constituents. For the physiological functions of the human body, the nutrients are essential. Such nutrients and biochemicals such as carbohydrates, fats, and proteins play an important role in satisfying human wants and need for energy and other life processes [4-6]. Over the past few decades, medicinal plants have widely been studied for the purpose of the mitigation and the treatment of various infectious diseases because microbial resistances against conventionally used synthetic antimicrobial agents are increasing at an alarming rate $[7,8]$. Each and every community has its own system of traditional medicine, and they utilize natural resources around their habitats for various medicinal purposes [9]. Many medicinal plants are used by marginal communities to cure various diseases [2] as diverse medicinal plant species are used either in the form of extract or decoction by the local people in different regions; therefore, evaluating their marginal significance can help to understand the worth of these plant species in different ecological conditions and few plants serve as both food and medicine. Euphorbia heterophylla is one of such plants [10]. It is commonly called Mexican fire plant, milk weed and spurge weed in English. Several chemical compounds such as friedelin, $\beta$-sitosterol, myricyl alcohol, ellagic acid, benzoic acid, diterpenes, stigmasterol, quercetin, and different amino acids are present in E. heterophylla [11]. This plant is native to Central and South America, but now observed in tropical and subtropical levels. E. heterophylla is herbaceous, erect and grows up to 20-200 $\mathrm{cm}$ in height. The morphological variation in the shape of the leaf has led to different species. The milky latex is acrid and the toxicity is neither alkaloid nor glycoside but probably a resin which can prove fatal [12]. Despite the toxicity hazard of this plant, it has various medicinal properties which include its use in the treatment of gonorrhea, respiratory tract infection, malaria, eczema, asthma, and wart cure [13].
In East Africa, E. heterophylla is used for the treatment of gonorrhea and to accelerate wound healing. It is also used as a purgative and lactogenic agent, as a cure for a migraine. The latex of the plant is also used as a fish poison and insecticide [14]. The latex is irritant to the skin and eyes and may be employed as a rubefacient and to remove warts and corns. E. heterophylla extract exhibited a wide spectrum of antibacterial action against Klebsiella pneumoniae, Staphylococcus aureus, Escherichia coli, and P. aeruginosa [15]. Antimicrobial drugs play a significant role on bacterial infections. Antimicrobial drugs have proved remarkably effective for the control of bacterial infections. However, there is an increased attention on extracts and biologically active compounds isolated from plant species used in herbal medicine due to the side effects and the resistance that pathogenic micro-organisms build against the antibiotics [16]. It was reported that infectious diseases caused by bacteria, fungi, viruses, and parasites are still a major threat to public health, despite the tremendous progress in human medicine. Their impact is particularly large in developing countries due to the relative unavailability of medicines and the emergence of widespread drug resistance [17].

\section{METHODS}

Collection and preparation of $E$. heterophylla latex extracts The plant E. heterophylla was collected from Pandavapura, Mandya district, Karnataka, in the month of January 2017. The fresh latex of the plant was obtained from the stems and the leaves early in the morning by capillary action using the amber glass screw cap bottle.

Based on the solubility, the stock solution was prepared. Thereafter, serial dilution of the stock solution was prepared to get various concentrations $(5 \%, 10 \%$, and $15 \%)$ of which were used for the antibacterial sensitivity test.

\section{Preliminary phytochemical analysis}

The plant extracts were assayed for the presence of alkaloids, flavonoids, tannins, resins, saponins, cardiac glycosides, and steroids [18]. 


\section{Antimicrobial activity}

Collection of bacterial cultures

All the bacteria, i.e., Staphylococcus aureus (MTCC 7443), B. subtilis (MTCC 121), P. vulgaris, and Pseudomonas aeruginosa (NCIM 2200) used for the detection of antibacterial activity were collected from the Department of Microbiology, Yuvaraja's College, Mysuru, and subcultured on nutrient agar slants. The nutrient agar high medium was prepared as per the requirement according to the number of plates, and the $\mathrm{pH}$ was adjusted to 7 . The media were sterilized by autoclave at $121^{\circ} \mathrm{C}$ for $15 \mathrm{~min}$. After sterilization, the nutrient agar medium was poured into sterile Petri plates under aseptic conditions and allowed for solidification.

\section{Preparation of bacterial inoculum}

A $2 \mathrm{ml}$ of double-distilled water was taken in a clean test tube and a loop full bacterial culture was suspended. Form this, $1 \mathrm{ml}$ of the sample was inoculated into the agar medium and kept for culturing.

\section{Antibacterial activity}

The bacterial subculture was spread uniformly over the medium using an L-shaped glass rod. Different concentrations of various extracts (acetone, chloroform, and diethyl ether) were impregnated onto the sterile discs of $0.1 \mathrm{~mm}$ diameter and were placed onto the plates. The latex extract along with standard drug tetracycline was also prepared $(50 \mathrm{mg} / \mathrm{ml})$ and impregnated onto separate discs which would serve as the control in determining the antibacterial activity. The plates were then incubated at $37^{\circ} \mathrm{C}$ overnight [19].

\section{Antifungal assay}

The fungal cultures such as Aspergillus niger, Penicillium sp., and Fusarium oxysporum were obtained from the Department of Microbiology of Yuvaraja's College, Mysuru. It was subcultured in the potato dextrose broth solution for further uses. Potato dextrose agar high medium was prepared according to the requirements and autoclaved at $121^{\circ} \mathrm{C}$ for $15 \mathrm{~min}$. After sterilization, the potato dextrose agar medium was poured into the sterile Petri plates under aseptic condition and allowed for solidification.

\section{Preparation of inoculum}

From subcultured broth solution, $1 \mathrm{ml}$ of the inoculum was taken in a clean sterile test tube and was made up to $2 \mathrm{ml}$ with sterile distilled water and shaken well. From this, $1 \mathrm{ml}$ of inoculum was inoculated into the plates.

\section{Antifungal activity}

The fungal subculture was spread uniformly over the medium using an L-shaped glass rod. Different concentrations of various extracts (acetone, chloroform, and diethyl ether) were impregnated onto the sterile discs of $0.1 \mathrm{~mm}$ diameter and were placed onto the plates. The latex extract along with standard drug fluconazole was prepared $(50 \mathrm{mg} / \mathrm{ml}$ ) and impregnated onto separate discs which would serve as the control in determining the antifungal activity. The treated plates were then incubated at $30^{\circ} \mathrm{C}$ for $24-48 \mathrm{~h}$.

Each experiment was carried out in triplicate. The standard deviation \pm mean of the inhibition zone was taken for evaluating the antimicrobial activity of the plant extracts.

\section{RESULTS}

Phytochemical analysis of $E$. heterophylla

Preliminary phytochemical studies revealed that the plant is rich in the compound such as carbohydrates, alkaloids, and flavonoids. Secondary metabolite identified in the plant material has been reported as having an inhibitory action against pathogenic microorganisms $[20,21]$. The result of phytochemical screening in E. heterophylla revealed the presence of secondary metabolites such as saponins, tannins, flavonoids, phenols, alkaloids, and steroids in different solvent extractions (Table 1). The primary metabolite like proteins was detected in diethyl ether, whereas the negligible amount of carbohydrates was found. In the present experimental work, the different extracts of E. heterophylla were tested

Table 1: The phytochemical screening of $E$. heterophylla latex extracts

\begin{tabular}{lllll}
\hline S. No. & Biochemical test & Acetone latex extract & Chloroform latex extract & Diethyl ether latex extract \\
\hline 1. & Benedicts test & - & - & - \\
2. & Froth test & + & - & + \\
3. & Xanthoproteic test & - & + & + \\
4. & Gelatin test & + & - & + \\
5. & Ferric chloride test & + & + & - \\
6. & Salkowski's test & - & + & + \\
7. & Ferric chloride test & + & + & + \\
8. & Hanger's test & + & - & - \\
9. & Test for steroids & - & + \\
10. & Test for cardioglycosidic acid & & + \\
\hline
\end{tabular}

Table 2: Zone of inhibition area in $\mathrm{mm}$ of the plant extracts against selected bacteria

\begin{tabular}{|c|c|c|c|c|c|c|c|c|c|c|c|c|}
\hline \multirow[t]{2}{*}{ Bacterial strain } & \multicolumn{3}{|c|}{ Acetone latex extract } & \multicolumn{3}{|c|}{ Chloroform latex extract } & \multicolumn{3}{|c|}{$\begin{array}{l}\text { Diethyl ether latex } \\
\text { extract }\end{array}$} & \multicolumn{3}{|c|}{$\begin{array}{l}\text { +ve control } \\
\text { (tetracycline) }\end{array}$} \\
\hline & $5 \%$ & $10 \%$ & $15 \%$ & $5 \%$ & $10 \%$ & $15 \%$ & $5 \%$ & $10 \%$ & $15 \%$ & & & \\
\hline Staphylococcus aureus & 6 & 8 & 9 & 4 & 8 & 9 & 6 & 7 & 9 & 11 & 13 & 11 \\
\hline Proteus vulgaris & 3 & 4 & 5 & 0 & 4 & 6 & 6 & 7 & 11 & 10 & 10 & 10 \\
\hline Bacillus subtilis & 5 & 7 & 10 & 4 & 5 & 9 & 6 & 7 & 8 & 5 & 11 & 8 \\
\hline Pseudomonas aeruginosa & 5 & 7 & 14 & 0 & 3 & 5 & 4 & 6 & 10 & 9 & 7 & 10 \\
\hline
\end{tabular}

Table 3: Zone of inhibition area in $\mathbf{m m}$ of the plant extracts against selected fungi

\begin{tabular}{|c|c|c|c|c|c|c|c|c|c|c|c|c|}
\hline \multirow[t]{2}{*}{ Fungal strains } & \multicolumn{3}{|c|}{ Acetone latex extract } & \multicolumn{3}{|c|}{ Chloroform latex extract } & \multicolumn{3}{|c|}{ Diethyl ether latex extract } & \multirow{2}{*}{\multicolumn{3}{|c|}{$\begin{array}{l}\text { +ve control } \\
\text { (fluconazole) }\end{array}$}} \\
\hline & $10 \%$ & $20 \%$ & $30 \%$ & $10 \%$ & $20 \%$ & $30 \%$ & $10 \%$ & $20 \%$ & $30 \%$ & & & \\
\hline Aspergillus niger & 5 & 12 & 16 & 7 & 11 & 13 & 15 & 17 & 2 & 3 & 5 & 3 \\
\hline Fusarium oxysporum & 0 & 2 & 10 & 0 & 0 & 3 & 0 & 6 & 9 & 0 & 0 & 0 \\
\hline Penicillium sp. & 1 & 7 & 11 & 2 & 6 & 9 & 4 & 10 & 15 & 6 & 0 & 0 \\
\hline
\end{tabular}


against the four bacterial strains of P. vulgaris, S. aureus, B. subtilis, and $P$. aeruginosa. The study carried out on $E$. heterophylla revealed the presence of bacterial activity (Table 2). The antifungal activity of different latex extracts was tested against the fungal strains by the disk diffusion method. The different latex extracts showed a zone of inhibition against the fungal activity of A. niger, F. oxysporum, and Penicillium sp. (Table 3).

\section{Antibacterial activity of $E$. heterophylla against $S$. aureus}

The experiment was carried out to determine the antibacterial activity of $E$. heterophylla latex extract against bacterial strain of $S$. aureus. It was observed that $S$. aureus exhibited similar to the zone of inhibition in acetone, chloroform, and diethyl ether extracts. It was observed that the zone of inhibition increased as the concentration of the extract increased (Fig. 1).

\section{Antibacterial activity of $\boldsymbol{E}$. heterophylla against $\boldsymbol{B}$. subtilis}

In the present investigation, the three different solvent extracts were tested against $B$. subtilis. A high potential zone of inhibition was seen in acetone extract in comparison to diethyl ether and chloroform extracts. It was observed that tetracycline which was used as a control showed a significant zone of inhibition against B. subtilis (Fig. 2).

\section{Antibacterial activity of $E$. heterophylla against $P$. vulgaris}

The result was recorded for the inhibitory activities against $P$. vulgaris in three different solvents. $P$. vulgaris showed a significant zone of inhibition in latex extract from diethyl ether. The result was far better than the standard drug tetracycline that was used as a control (Fig. 3).

\section{Antibacterial activity of $E$. heterophylla against $P$. aeruginosa}

The experiment was carried out to determine the antibacterial activity of E. heterophylla latex extract against bacterial strain of $P$. aeruginosa. A high potential zone was observed in acetone latex extract against $P$. aeruginosa whereas in chloroform, and diethyl ether exhibited moderate activity (Fig. 4). The bacterial strains possessed a substantial zone of inhibition compared to tetracycline in acetone extract.

\section{Antifungal activity of $E$. heterophylla against $A$. niger}

The studies were carried out to evaluate the antifungal activity of E. heterophylla latex extract against A. niger. A significant zone of inhibition was observed in acetone, chloroform, and diethyl ether extracts. When these extracts were compared with the standard drug fluconazole, the inhibition zone was excellent and can be placed on record (Fig. 5).

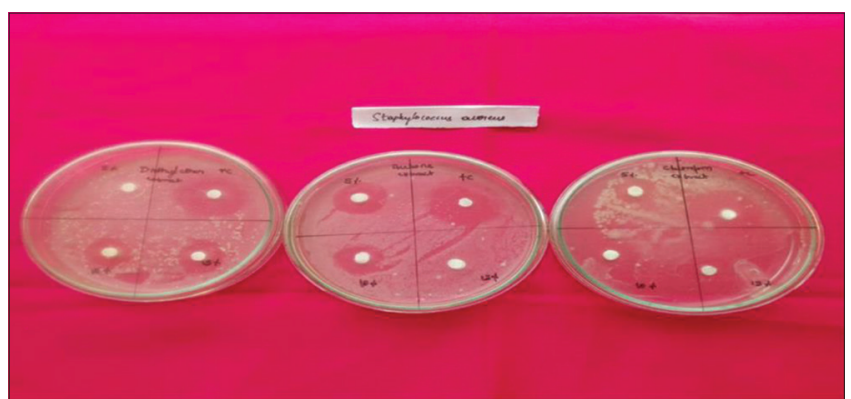

Inhibition zone shown by the latex extract against Staphylococcus aureus

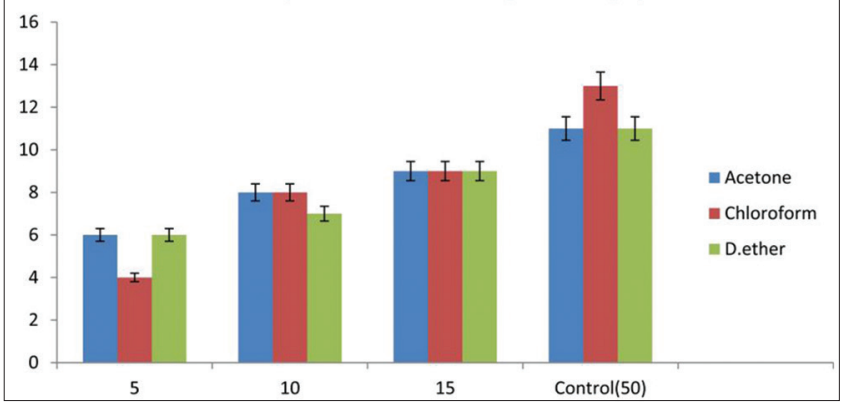

Fig. 1: Graphical representation of inhibition zone antibacterial activity of latex extract against Staphylococcus aureus (standard deviation \pm mean $* \mathrm{p}<0.05,{ }^{* *} \mathrm{p}<0.005$ )
Antifungal activity of $E$. heterophylla against $F$ oxysporum

The result was recorded for the inhibitory activity against F. oxysporum.Based on the concentration of three different solvents, a considerable zone of inhibition was documented. F. oxysporum is resistant to standard drug fluconazole and showed no zone of inhibition (Fig. 6). Diethyl ether and acetone extracts can be used in antifungal activity.

\section{Antifungal activity of $E$. heterophylla against Penicillium sp.}

During the investigation, the solvent extracts were tested against Penicillium sp. The zone of inhibition in Penicillium sp. was concentration dependent. Higher the concentration greater is the zone of inhibition. Penicillium sp. exhibited a high potential zone of inhibition in diethyl ether extract. Fungus was resistant to fluconazole which was used as

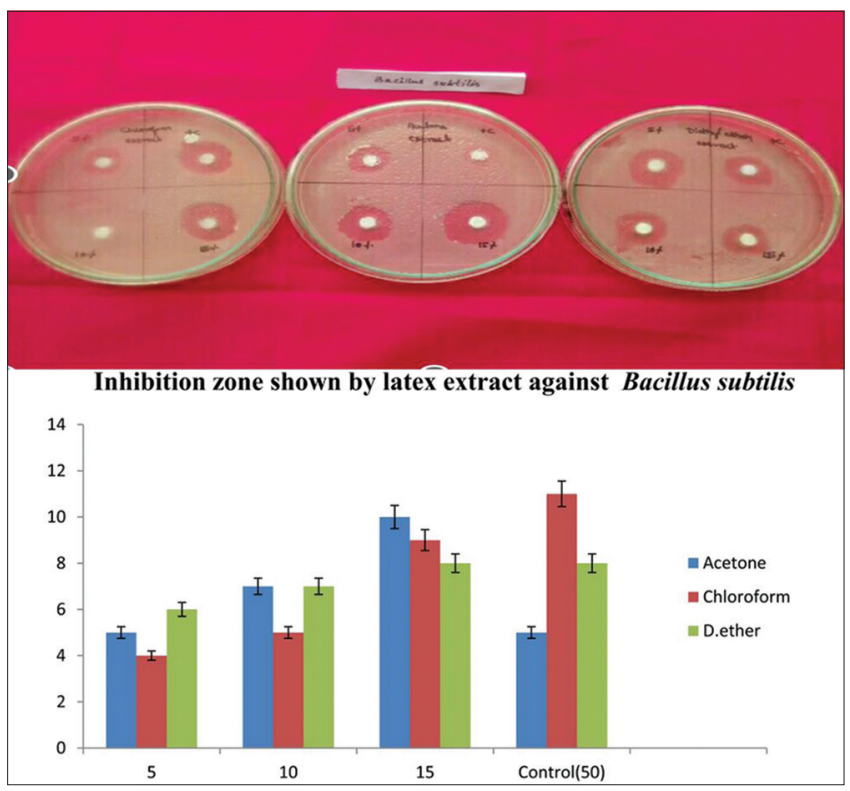

Fig. 2: Graphical representation of inhibition zone antibacterial activity of latex extract against Bacillus subtilis (standard deviation \pm mean ${ }^{*} \mathbf{p}<0.05,{ }^{* *} \mathbf{p}<0.005$ )

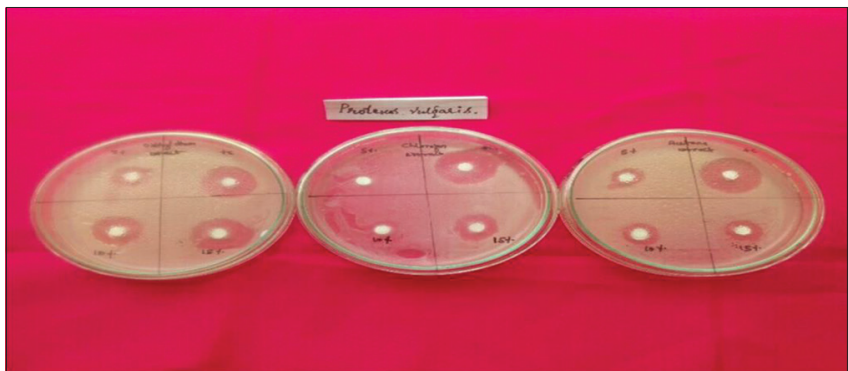

Inhibition zone shown by latex extract against Proteus vulgari

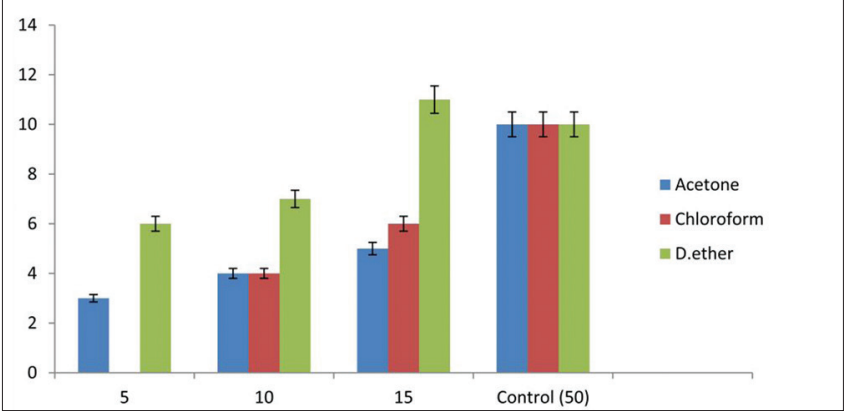

Fig. 3: Graphical representation of inhibition zone antibacterial activity of latex extract against Proteus vulgaris (standard deviation \pm mean $* \mathrm{p}<0.05, * * \mathrm{p}<0.005$ ) 


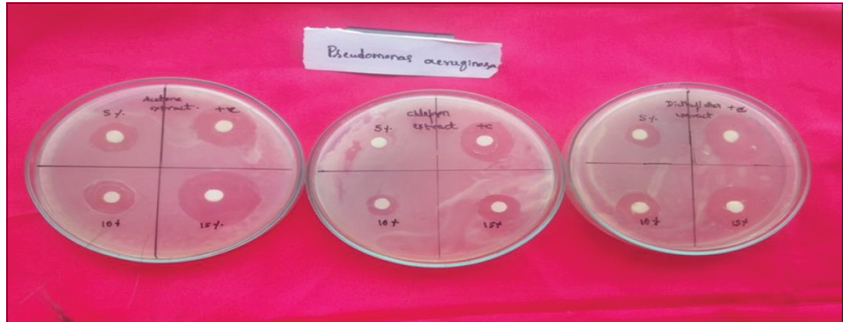

Inhibition zone shown by latex extract against Pseudomonas aeruginosa

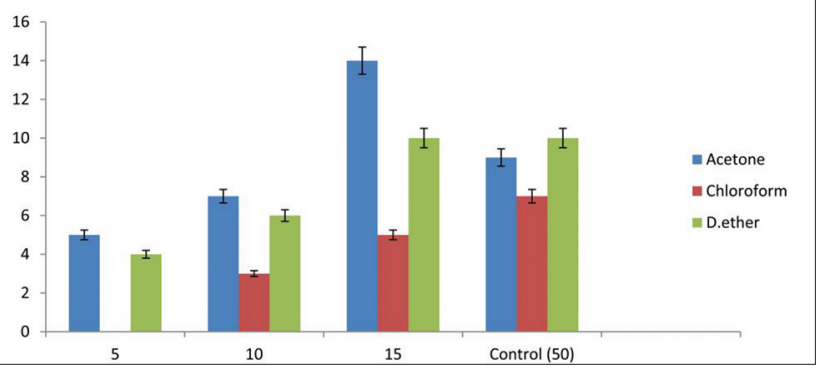

Fig. 4: Graphical representation of inhibition zone antibacterial activity of latex extract against Pseudomonas aeruginosa (standard deviation \pm mean ${ }^{*} \mathbf{p}<0.05,{ }^{* *} \mathbf{p}<0.005$ )
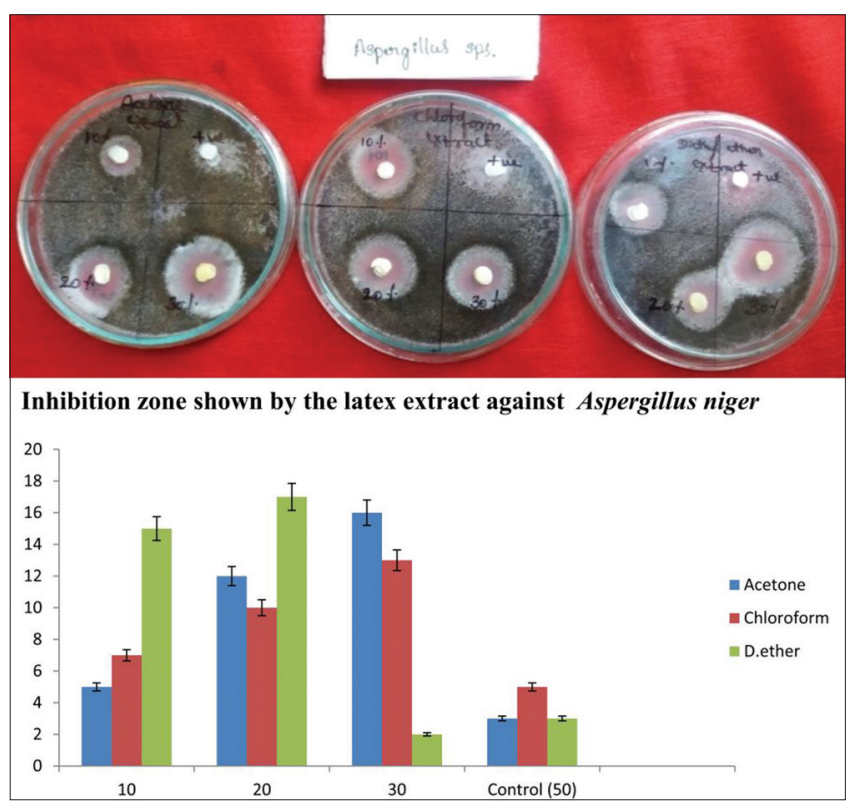

Fig. 5: Graphical representation of inhibition zone antibacterial activity of latex extract against Aspergillus niger (standard deviation \pm mean ${ }^{*} \mathbf{p}<0.05,{ }^{* *} \mathbf{p}<0.005$ )

a control (Fig. 7). Hence, diethyl ether extract of E. heterophylla can be used as a standard drug.

\section{DISCUSSION}

The study carried out on the plant latex revealed the presence of active metabolites. The phytochemical analysis, in acetone latex extract of the plant, showed considerable results in saponins, tannins, flavonoids, phytosterols, alkaloids, and steroids. There was no result found in carbohydrates, proteins, phenols, and cardioglycosidic acid. Chloroform latex extract of the plant showed significant results in saponins, tannins, flavonoids, phenols, alkaloids, and steroids. It showed the insignificant result in carbohydrates, proteins, phytosterols, and cardioglycosidic acid. Diethyl ether latex extract of plant showed positive results in saponins, proteins, tannins, alkaloids, steroids, and cardioglycosidic
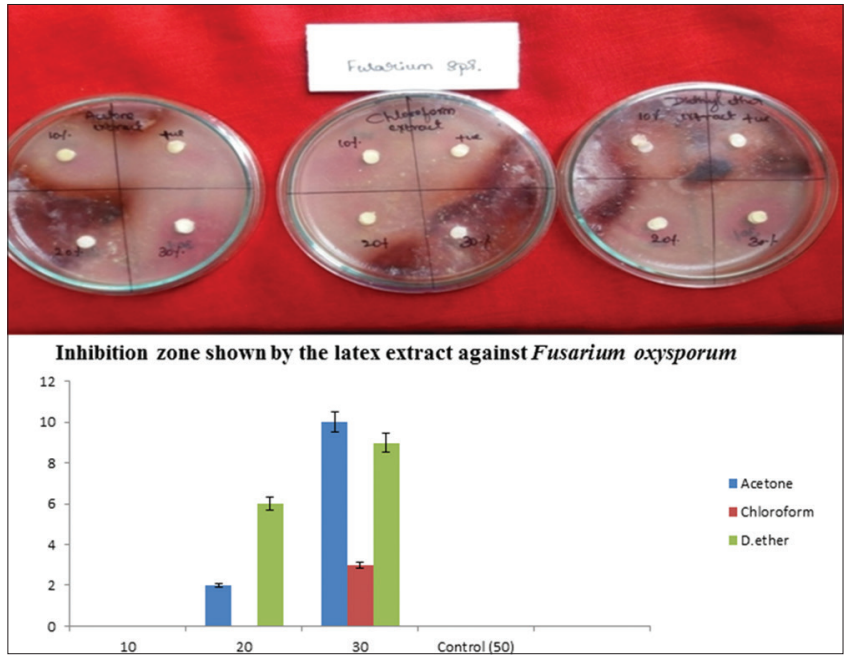

Fig. 6: Graphical representation of inhibition zone antibacterial activity of latex extract against Fusarium oxysporum (standard deviation \pm mean ${ }^{*} \mathbf{p}<0.05,{ }^{* *} \mathbf{p}<0.005$ )

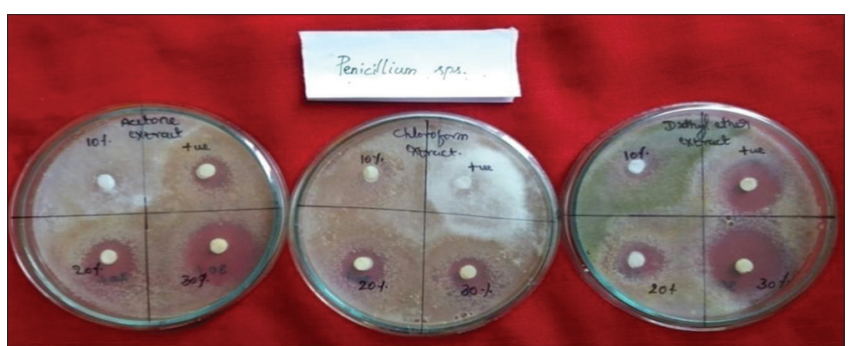

Inhibition zone shown by the latex extract against Penicillium sps.

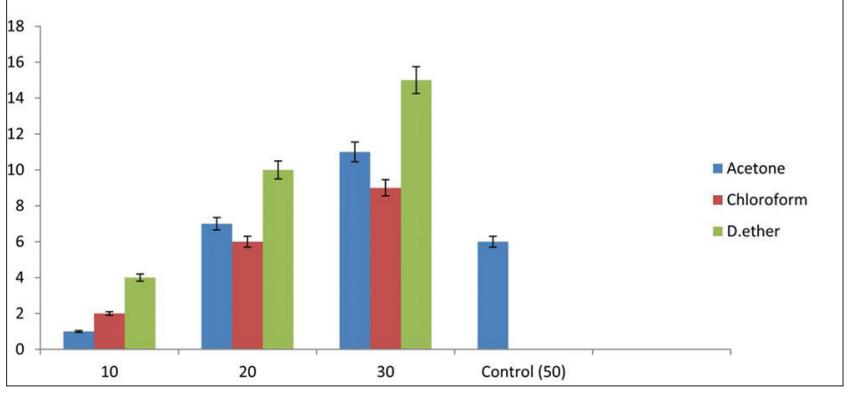

Fig. 7: Graphical representation of inhibition zone antibacterial activity of latex extract against Penicillium sp. (standard deviation \pm mean $* \mathbf{p}<0.05,{ }^{* *} \mathbf{p}<0.005$ )

acid, and no result was seen in carbohydrates, flavonoids, phytosterols, and phenols.

The latex extract showed good antibacterial activity against $P$. vulgaris, S. aureus, B. subtilis, and P. aeruginosa and exhibited good zone of inhibition against the fungal activity of $A$. niger, Penicillium sp., and F. oxysporum. In a study, it was reported that diethyl ether extract of latex of E. heterophylla exhibited significant antibacterial activity against $S$. aureus and $P$. aeruginosa.

\section{CONCLUSION}

The presence of saponins and alkaloids has been reported to be responsible for various pharmacological properties, by exerting toxic effects against cells of foreign organisms. In general, E. heterophylla latex extract was found to be more potent than the standard drugs which were used against both the bacterial and fungal strains. 


\section{ACKNOWLEDGMENT}

The authors are grateful to the authorities of Yuvaraja's College and Teresian College, Mysuru, for providing the required facilities.

\section{AUTHORS' CONTRIBUTIONS}

Pruthvi and Rohini have prepared the manuscript under the guidance of Dr. Mahesh.

\section{CONFLICTS OF INTEREST}

The authors declare that they have no conflicts of interest.

\section{REFERENCES}

1. Prajapati ND, Prajapati T. Sustainable cultivation of medicinal plants, multitier agriculture system-a new concept. In: Biochemistry. $3^{\text {rd }}$ ed. United States: Benjamin Cummings; 2002.

2. Latif A, Almad H, Begun S, Adnan M, Hussain WM. Medicinal and Other Economic Plant as Substitute to Forest Logging in Miandam and Sulatat Valleys, Swat. Pakistan: Proceedings of International Workshop on Conservation and Sustainable Use of Medicinal and Aromatic Plants in Pakistan; 2003. p. 101-5.

3. Shinwari ZK, Pehman M, Watanabe T, Yoshikawa T. A Pictorial Guide to Medicinal Plants of Pakistan. Kohat: Kohat University of Science and Technology; 2006.

4. Hoffman PC, Combs DK, Caster MD. Performance of lactating dairy cows fed alfalfa silage or perennial ryegrass silage. J Dly Sci 1998;81:162-8.

5. Mathews CE, Vanholds KE, Ahem KG. Biochemistry. $3^{\text {rd }}$ ed. United States: Benjamin Cummings; 1999.

6. Dingman SL. Water in soils: Infiltration and redistribution. In: Physical Hydrology. $2^{\text {nd }}$ ed. Upper Saddle River, New Jersey: Prentice-Hall, Inc.; 2002. p. 646.

7. Difuntorum YS, Touami S. In vitro antimicrobial activity of GSQ1530, a new heteroaromatic polycyclic compound. Antimicrob Agents Chemother 2002;46:3168-74.

8. Nair R, Chanda S. Anticandidal activity of Punica granatum exhibited in different solvents. Pharm Biol 2005;43:21-25.

9. Mary S, Mahesh MK. Antimicrobial activity of Asclepias curassavica flower extract. J BioInnov 2014;3:261-8.

10. Latif A, Almad H, Begun S, Adnan M, Hussain WM. Medicinal and Other Economic Plant as Substitute to Forest Logging in Miandam and Sulatat Valleys, Swat. Pakistan: Proceedings of International Workshop on Conservation and Sustainable Use of Medicinal and Aromatic Plants in Pakistan; 2003. p. 101-5.

11. Adnan M, Holscher D. Medicinal plant abundance in degraded and reforested sites in Northwest Pakistan. Mt Res Dev 2010;30:25-32.

12. Omale J, Emmanuel F. Phytochemical composition, bioactivity and wound healing potential of Euphorbia heterophylla (Euphorbiaceae) leaf extract. Int J Pharm Biomed Res 2010;1:54-63.

13. Jaiyesimi AA, Abo A. Phytochemical and antimicrobial analysis of the crude extract, petroleum ether and chloroform fractions of Euphorbia heterophylla L whole plant. Pharmacogn J 2010;2:1-4.

14. Hartwell JL. Plants used against cancer. A survey. Lloydia 1969;32:247-96.

15. Okeniyi SO, Adedoyin BJ, Garba S. Phytochemical screening, cytotoxicity, antioxidant and antimicrobial activities of stem and leave extracts of Euphorbia heterophylla. J Biol Life Sci 2013;4:2157-6076.

16. Ughachukwu PO, Ezenyeaku CC, Ochiogu BC, Ezeagwuna DA, Anahalu IC. Evaluation of antibacterial activities of Euphorbia heterophylla. IOSR J Dent Med Sci 2014;13:69-75.

17. Essawi T, Srour M. Screening of some Palestinian medicinal plants for antibacterial activity. J Ethnopharmacol 1999;70:343-9.

18. Okeke IN, Laxmaninaraya R, Bhutta ZA, Duse AG, Jenkins P, O'Brien TF, et al. Antimicrobial resistance in developing countries. Part I: Recent trends and current status. Lancet Infect Dis 2005;5:481-93.

19. Harborne JB. Phytochemical Methods. London: Chapman and Hall Ltd.; 1973. p. 49-188.

20. Bauer A, Kirby WM, Sherris JC, Truck M. Antibiotic susceptibility testing by a standardized single disk method. Am J Clin Pathol 1966;36:493-6.

21. Freeman BC, Beattle GA. An overview of plant defenses against pathogens and herbivores. Plant Health Instr 2008. DOI: 10.1094/ PHI-I-2008-0226-01.

22. Xiao-Tian L, Wei-Shuo F. Medicinal Chemistry of Bioactive Natural Products. Hoboken: John Wiley and Sons, Inc.; 2006. 